\title{
PULMONARY CIRCULATION IN CHRONIC BRONCHITIS AND EMPHYSEMA
}

\author{
BY \\ DAVID B. SHAW,* ROBERT F. GROVER, J. T. REEVES, AND \\ GILBERT BLOUNT, JR. \\ From the Section of Cardiology, University of Colorado Medical Center, Denver, Colorado, U.S.A.
}

Received June 24, 1964

Hypoxia is usual in patients with severe pulmonary emphysema, and the way in which they adapt to it may be crucial to their survival. Two means of maintaining tissue oxygenation which might be employed by the emphysematous patient are increased erythropoiesis to raise the oxygen-carrying capacity of the blood, and increased cardiac output to raise the rate of blood flow to the tissue.

It might be possible to predict the adaptive mechanisms in emphysema by using Barcroft's (1925-28) analogy between the healthy mountain dweller, hypoxic due to the low oxygen tension of ambient air, and the patient at sea-level, hypoxic due to lung disease. There is an impressive body of evidence that in the high altitude resident, a major adaptation is the rise in red cell count which parallels the fall in arterial oxygen saturation with increasing altitude, while the cardiac output remains virtually unchanged (Hurtado, Merino and Delgado, 1945; Peñaloza et al., 1963). Early studies on patients with pulmonary emphysema suggested that quite the opposite form of adaptation occurred in this condition. Thus, Wilson, Borden, and Ebert (1951) found no hæmatological response to hypoxia, and McMichael and Sharpey-Schafer (1944) reported a significant increase in cardiac output in emphysema. However, it has now been shown that the red cell volume increases to a normal extent in response to hypoxia in emphysema (Shaw and Simpson, 1961), while recent reports of cardiac output in emphysema are contradictory. Thus it has been suggested that the cardiac output at rest is increased, normal, or decreased, and that the response of the cardiac output to exercise is reduced or normal (Harvey et al., 1951; Yu et al., 1953; Williams and Zohman, 1959).

One explanation (which has been suggested) for the conflicting findings in emphysema is that cardiac output represents a balance between the opposing effects of hypoxia and pulmonary arterial hypertension (Williams and Zohman, 1959; Aber, Bayley, and Bishop, 1963). However, it is difficult to assess the significance of the divergent findings of different workers, because they have used different definitions of the "normal" cardiac output. Further, the results of studies of emphysematous patients in one laboratory have been compared with those of normal subjects in another.

The work here is a study of the cardiac output, and its relationship to pulmonary hypertension and hypoxia in emphysematous patients at rest and during exercise in the supine and erect posture. The findings are compared with data previously obtained from normal subjects studied under similar conditions in the same laboratory.

\section{SubJeCtS AND METHODS}

Patients. Studies were carried out on 39 male and 3 female subjects suffering from chronic irreversible obstructive airway disease associated with chronic bronchitis or emphysema or both. The diagnosis was made by clinical history, physical examination, and pulmonary function data. All had a history of dyspnoea

* Present address: Royal Devon and Exeter Hospital, Exeter, Devon. 
TABLE I

Basic Data on Emphysematous Patients*

\begin{tabular}{|c|c|c|c|c|c|c|c|c|}
\hline Subjects & No. & $\begin{array}{l}\text { Mean } \\
\text { age } \\
\text { (yr.) }\end{array}$ & $\begin{array}{c}\text { Mean } \\
\text { arterial } \\
\text { oxygen } \\
\text { saturation } \\
(\%)\end{array}$ & $\begin{array}{c}\text { Mean } \\
\text { pulmonary } \\
\text { artery } \\
\text { plasma CO } \mathrm{CO}_{2} \\
\text { content } \\
\text { Vol. } \%\end{array}$ & $\underset{(\mathrm{mm} . \mathrm{Hg})}{\text { Mean }}$ & $\begin{array}{c}\text { Mean } \\
\text { MBC } \neq \\
\% \text { of } \\
\text { normal }\end{array}$ & $\begin{array}{c}\text { Mean } \\
\text { hæmoglobin } \\
\text { (g./100 ml.) }\end{array}$ & $\underset{\substack{\text { Mean } \\
\text { hæmatocrit }}}{\substack{\% \\
\text { hen }}}$ \\
\hline $\begin{array}{l}\text { Resting } \\
\text { Supine exercise } \\
\text { Treadmill exercise } \\
\text { Normal** }^{* *} \quad .\end{array}$ & $\begin{array}{l}41 \\
17 \\
18 \\
-\end{array}$ & $\begin{array}{l}52 \\
49 \\
51 \\
-\end{array}$ & $\begin{array}{l}81 \\
80 \\
87 \\
94\end{array}$ & $\begin{array}{l}52 \\
50 \\
52 \\
42\end{array}$ & $\begin{array}{l}35 \\
37 \\
32 \\
16\end{array}$ & $\begin{array}{r}32 \\
37 \\
28 \\
100\end{array}$ & $\begin{array}{l}15 \\
15 \\
16 \\
-\end{array}$ & $\frac{51 \S}{49}$ \\
\hline
\end{tabular}

* Normal mean resting values at Denver (5280 feet) are given in the lowest column. The resting data is from 41 subjects only, since in one instance no oxygen uptake was obtained at rest.

$\uparrow$ PAP, pulmonary artery pressure.

$\ddagger$ MBC, maximum breathing capacity.

$\S$ On 24 patients only.

** Anderson et al. (1953) and unpublished data.

TABLE II

Distribution of Values for Arterial Oxygen Saturation and Mean Pulmonary Arterial Pressure at Rest in 41 EMPhysematous PatiEnts

\begin{tabular}{c|c|c|c}
\hline $\begin{array}{c}\text { Arterial oxygen } \\
\text { saturation (\%) }\end{array}$ & $\begin{array}{c}\text { No. of } \\
\text { subjects }\end{array}$ & $\begin{array}{c}\text { Mean pulmonary } \\
\text { arterial pressure } \\
\text { (mm. Hg) }\end{array}$ & $\begin{array}{c}\text { No. of } \\
\text { subjects }\end{array}$ \\
\hline $95-90 \cdot 1$ & 11 & $15-19$ & 1 \\
$90-85 \cdot 1$ & 5 & $20-24$ & 7 \\
$85-80 \cdot 1$ & 10 & $25-29$ & 10 \\
$80-75 \cdot 1$ & 6 & $30-39$ & 12 \\
$75-70 \cdot 1$ & 3 & $40-49$ & 6 \\
$70-65 \cdot 1$ & 2 & $50-59$ & 2 \\
Under 65.1 & 4 & Over 59 & 3 \\
\hline
\end{tabular}

for at least two years without obvious cause other than emphysema, or bronchitis. Three-quarters of the patients gave a history of chronic productive cough for two years or more; in five cases it was not possible to determine whether a productive cough existed. No patients are included who were known to have been in cardiac failure within four weeks of catheterization, but three patients had been in cardiac failure and had recovered between one and twelve months before study. All patients had an impairment of ventilatory function (maximum breathing capacity below $63 \%$ of normal), and the total lung capacity was increased (more than $110 \%$ of normal) in 20 of the 25 patients in whom it was measured. Thirty patients had an arterial saturation below 90 per cent and all but one had a mean pulmonary artery pressure above $19 \mathrm{~mm}$. $\mathrm{Hg}$ at rest. Additional data on these patients are given in Tables I, II, and III. Necropsies have been carried out on ten of the patients; all showed the pathological changes of emphysema, and evidence of bronchitis was present in six.

All studies were carried out in Denver (altitude 5,280 ft.). The oxygen consumption was not measured at rest in one subject (No. 2477), and in the presentation of resting data this subject has been excluded. Exercise studies were carried out in 33 patients, 17 in the supine position using bicycle pedals, and 18 in the erect posture on a treadmill ( 2 patients were studied in both postures). Little or no sedation was used. A cardiac catheter was introduced from a peripheral vein through the right heart into the pulmonary artery where it remained throughout the study. Cardiac output was determined by the direct Fick method for oxygen at 
TABLE III

Blood a-v Oxygen Difference and Oxygen Consumption in Emphysema Patients at Rest and During EXERCISE

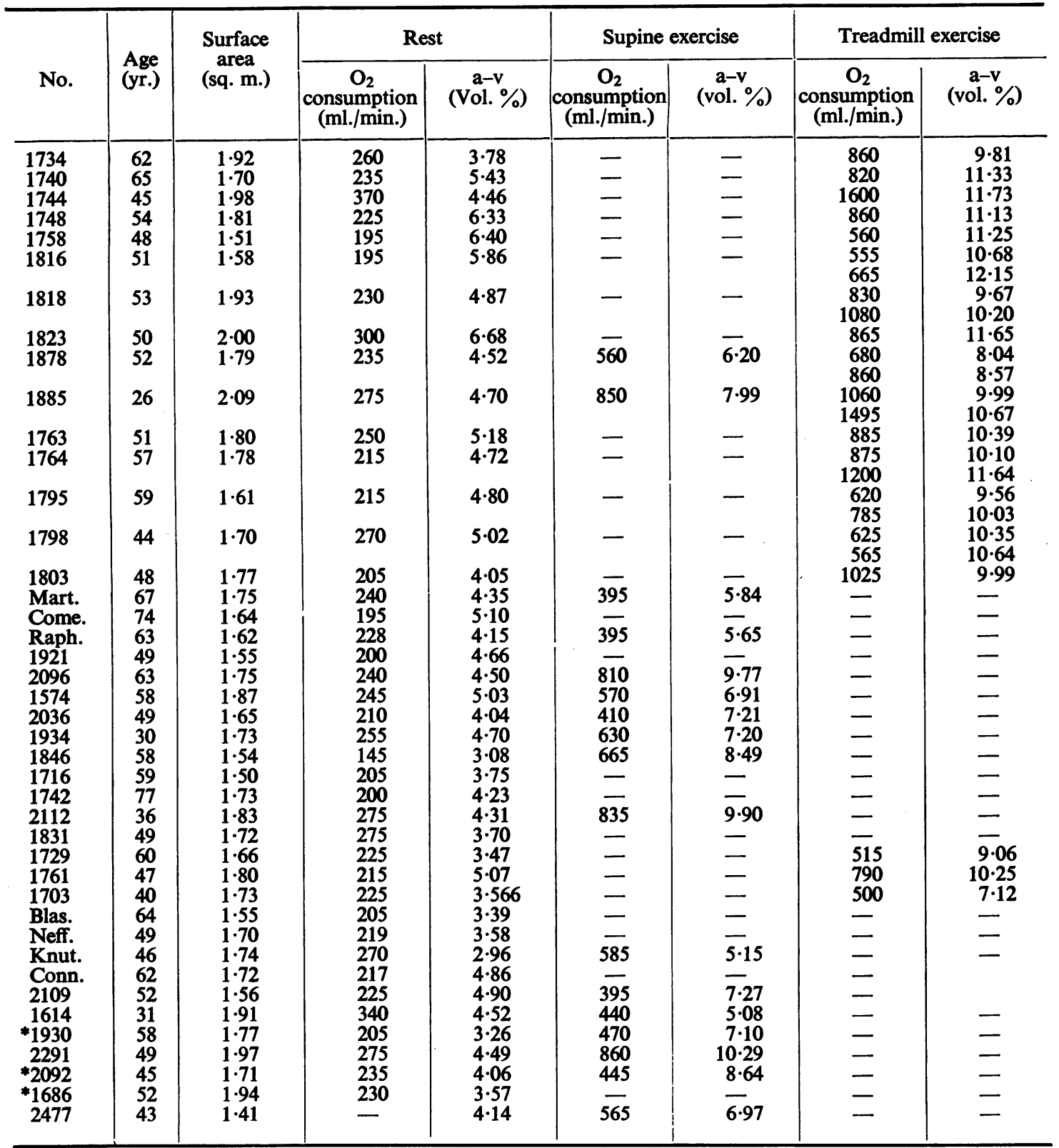

* Female patients.

rest and during supine and treadmill exercises. Exercise was performed for periods of six to ten minutes. Expired air was collected during the final two minutes of exercise, and concurrently, samples of mixed venous and arterial blood were drawn. Under these conditions, a "steady state" was attained (Blount, 1959). Blood samples were analysed by the method of Van Slyke and Neill, and samples of expired air were analysed 
TABLE IV

Cardiac OutPut and Oxygen Consumption for Emphysema (E) and Normal (N) SubJects

\begin{tabular}{|c|c|c|c|c|c|c|c|}
\hline $\begin{array}{l}\text { Position of } \\
\text { subjects }\end{array}$ & $\begin{array}{l}\text { No. of } \\
\text { subjects }\end{array}$ & $\begin{array}{l}\text { No. of } \\
\text { obser- } \\
\text { vations }\end{array}$ & $\begin{array}{c}\text { Mean } \mathrm{O}_{2} \\
\text { consumption } \\
\text { (ml./min.) }\end{array}$ & $\begin{array}{c}\text { Mean } \\
\text { cardiac } \\
\text { output } \\
\text { (1./min.) }\end{array}$ & $\begin{array}{l}\text { Mean a-v } \\
\text { difference } \\
(\mathrm{ml} . \%)\end{array}$ & $\begin{array}{c}\text { S.E. of } \\
\text { mean a-v } \\
\text { differ- } \\
\text { ence }\end{array}$ & $\begin{array}{c}\text { Significance } \\
\mathbf{p}\end{array}$ \\
\hline 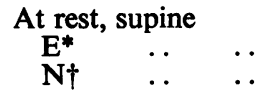 & $\begin{array}{l}41 \\
53\end{array}$ & $\begin{array}{l}41 \\
63\end{array}$ & $\begin{array}{l}236(145-370) \\
221(135-360)\end{array}$ & $\begin{array}{l}5 \cdot 48 \\
5 \cdot 63\end{array}$ & $\begin{array}{l}4.49 \\
3.98\end{array}$ & $\begin{array}{l}0.13 \\
0.07\end{array}$ & $<0.01$ \\
\hline $\begin{array}{ccc}\text { Supine, } & \text { exercise } & \\
\mathbf{E}^{*} & \ldots & \ldots \\
\mathbf{N}^{\dagger} & \ldots & .\end{array}$ & $\begin{array}{l}17 \\
17\end{array}$ & $\begin{array}{l}17 \\
17\end{array}$ & $\begin{array}{l}580(395-860) \\
620(370-845)\end{array}$ & $\begin{array}{l}8 \cdot 1 \\
8 \cdot 8\end{array}$ & $\begin{array}{l}7 \cdot 38 \\
7 \cdot 01\end{array}$ & $\begin{array}{l}0 \cdot 38 \\
0 \cdot 30\end{array}$ & $>0.4$ \\
\hline 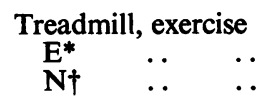 & $\begin{array}{l}10 \\
10\end{array}$ & $\begin{array}{l}12 \\
14\end{array}$ & $\begin{array}{l}1055(860-1600) \\
1100(850-1570)\end{array}$ & $\begin{array}{l}10 \cdot 1 \\
10 \cdot 6\end{array}$ & $\begin{array}{l}10 \cdot 49 \\
10 \cdot 38\end{array}$ & $\begin{array}{l}0 \cdot 28 \\
0 \cdot 26\end{array}$ & $>0.7$ \\
\hline
\end{tabular}

Note: Range is given in parentheses.

* Emphysema patients.

$\dagger$ Normal subjects.

by the micro-Scholander technique. The accuracy of the methods in this laboratory is given in Reeves et al. (1961b).

Table I shows that the patients exercised in the supine position were similar to the whole group of patients as regards age, maximum breathing capacity, arterial oxygen saturation, and mean pulmonary artery pressure. Those exercised in the erect posture were similar to the entire group in age, but tended to be less hypoxic and to have a more severe ventilatory disturbance (as judged by arterial oxygen saturation and maximum breathing capacity, respectively).

\section{RESULTS}

The results are set out in Tables III and IV.

Supine Rest. The mean cardiac output of the 41 emphysematous patients at rest was 5.48 1./min., which is not significantly different from the mean value of $5.631 . / \mathrm{min}$. for 53 normal subjects. Furthermore, when cardiac output is related to oxygen consumption the slopes of the regression lines of the data for the emphysematous patients and for the normal subjects are not significantly different, the slopes being 0.0215 and $0.02181 . / \mathrm{ml}$., respectively $(\mathrm{p}>0.7)$.

The mean arterio-venous (a-v) oxygen difference at rest for all the emphysematous patients was wider than normal, the values being 4.49 and 3.98 vol. per cent, respectively $(p<0.01)$. A similar difference was observed when the mean a-v difference of the 38 male patients was compared with the mean of 42 estimations in 38 normal male subjects, the values being 4.56 and 4.08 vol. per cent, respectively $(p<0.01)$. Six of the patients had a-v differences wider than the upper limit of normal of 5.14 vol. per cent and 18 had values greater than one standard deviation above the normal mean; none had differences narrower than the normal (Table III and Fig. 1).

The a-v difference was related to the arterial oxygen saturation in the 41 emphysematous patients studied at rest $(r=0.4, p<0.02)$. No significant correlation could be shown between the $a-v$ difference and the mean pulmonary arterial pressure $(p>0 \cdot 3$, degrees of freedom 39$)$.

Supine Exercise. The patients with emphysema did not achieve high levels of exertion, the mean oxygen consumption being only $580 \mathrm{ml} . / \mathrm{min}$. (range $395-860 \mathrm{ml} . / \mathrm{min}$ ). However, this level of exercise was sufficient to increase the mean pulmonary arterial pressure by an average of $21 \mathrm{~mm}$. $\mathrm{Hg}$. The range of values for the maximum mean pulmonary artery pressure attained was $26-95 \mathrm{~mm}$. $\mathrm{Hg}$. The patients were only slightly more hypoxic during exertion than at rest; the arterial oxygen saturation decreased by an average of $2 \cdot 1$ per cent. 


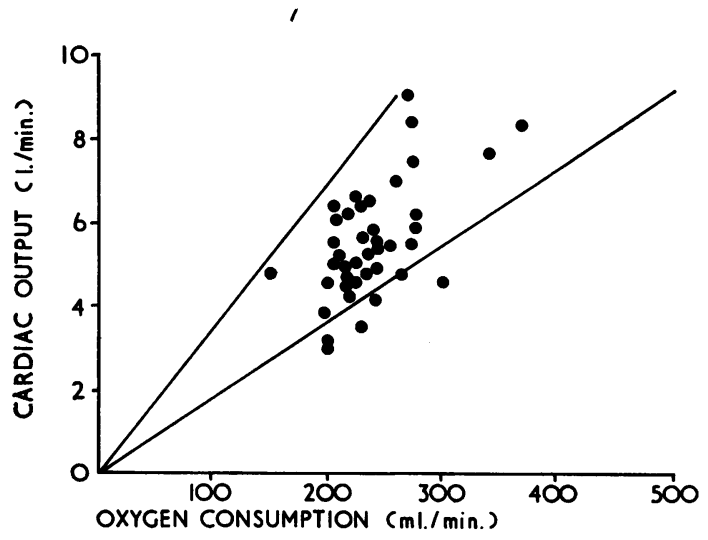

FIG. 1.-Cardiac output is plotted against oxygen consumption in 41 resting patients with chronic irreversible obstructive airway disease. Two isopleths of a-v oxygen difference representing the upper and lower limits of the normal (2.82 and 5.14 vol. $\%$ ) are drawn. Six points lie outside the line representing the upper limit for normal.

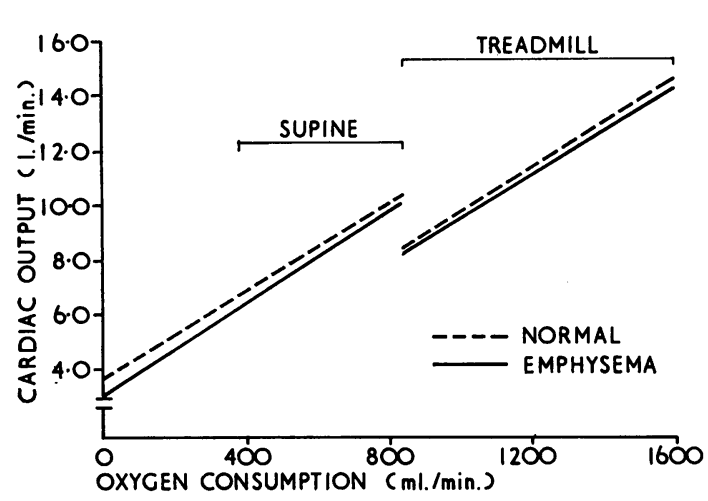

FIG. 3.-Regression lines for the relationship of cardiac output to oxygen consumption during supine and treadmill exercise in the patients with obstructive airways disease are plotted beside the regression lines for normal subjects.

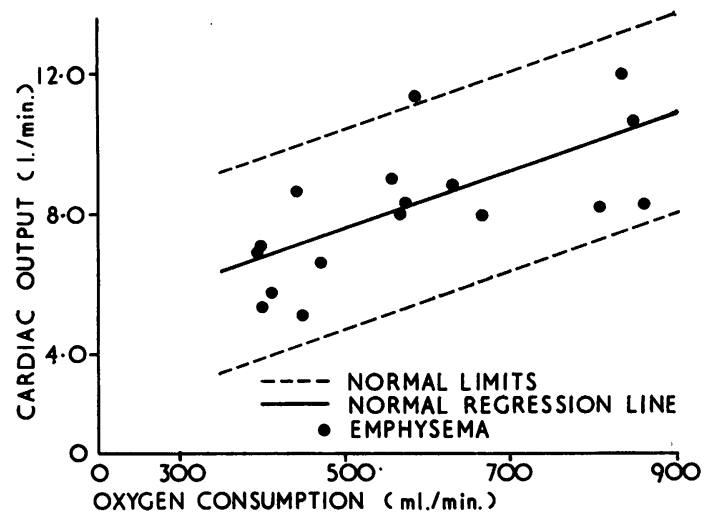

FIG. 2.-The cardiac output of 17 emphysematous patients exercising in the supine position is plotted against their oxygen consumption. The regression line and the lines for \pm twice the standard error of the estimate for 17 normal subjects exercising under similar conditions are given for comparison (Reeves et al., 1961c).

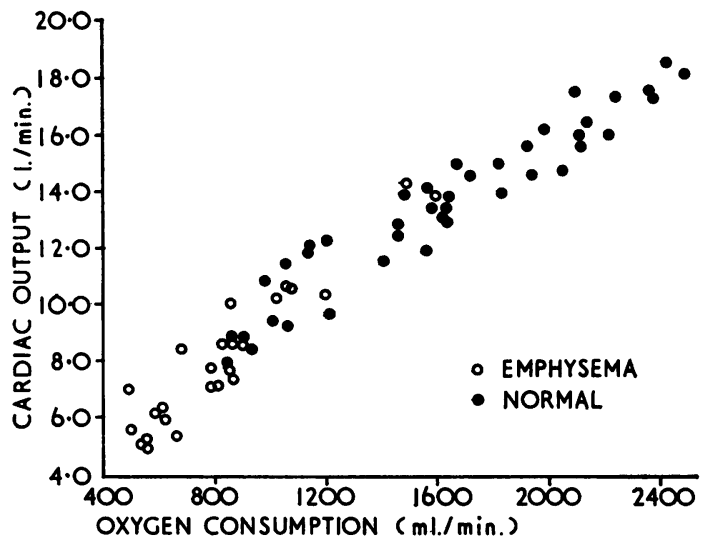

FIG. 4.-The relationship of cardiac output to oxygen consumption of 18 patients (25 estimations) and that of 10 normal subjects (41 estimations) during treadmill exercise (Reeves et al., 1961a).

Table IV and Fig. 2 and 3 compare the data from the emphysematous patients with those obtained from 17 normal subjects who performed similar levels of exercise (the mean oxygen uptake being $620 \mathrm{ml} . / \mathrm{min}$. and the range $370-845 \mathrm{ml} . / \mathrm{min}$.) The general trend of the relationship of cardiac output to oxygen consumption is similar in both groups of subjects, slopes of the regression lines being $0.00881 . / \mathrm{ml}$. in emphysema and $0.00821 . / \mathrm{ml}$. in normal subjects $(\mathrm{p}>0.4)$. Similarly, there is no significant difference between the mean a-v difference for the two groups, the values being $7 \cdot 38$ and 7.01 vol. per cent for the emphysematous and normal subjects respectively $(p>0.4)$.

Treadmill Exercise. Eighteen patients with emphysema were studied while they performed 25 stints of exercise on the treadmill. The mean pulmonary arterial pressure increased by an average of $24 \mathrm{~mm}$. $\mathrm{Hg}$ and the maximum in individual patients ranged from 35 to $105 \mathrm{~mm}$. $\mathrm{Hg}$. They became slightly more hypoxic during exertion, the arterial oxygen saturation falling by an average of 4.13 per cent. For these 18 patients, the 25 determinations of cardiac output are related to oxygen 
consumption in Fig. 4, and plotted for comparison are 41 estimations of cardiac output from 10 normal subjects (Reeves et al., 1961a). It appears from the figure that the cardiac output in the emphysematous patients walking on the treadmill is similar to the normal.

The oxygen consumption of 8 of the emphysematous patients during treadmill exercise was below that of the normal subjects reported by Reeves et al. (1961a). For statistical purposes, the 12 values of cardiac output for 10 patients who attained oxygen consumptions of $850-1600 \mathrm{ml} . / \mathrm{min}$. are compared with the 14 results from 10 normal subjects whose exercise oxygen consumptions were within this range. The mean oxygen consumptions for the two groups are very similar, the values being 1055 and $1100 \mathrm{ml} . / \mathrm{min}$. for the emphysematous and the normal subjects, respectively (Table IV). The mean values for the a-v difference in the two groups were also similar, being 10.49 and 10.38 vol. per cent, respectively ( $p>0 \cdot 7)$. When cardiac output is related to oxygen uptake (Fig. 3 ), the regression lines for the two groups have slopes which are not significantly different, the values being 0.00761 ./mil. in emphysema compared with $0.00791 . / \mathrm{ml}$. for normal subjects $(\mathrm{p}>0.7)$. For these 10 selected emphysema patients the average rise in mean pulmonary artery pressure of $25 \mathrm{~mm}$. $\mathrm{Hg}$ and the average decrease in arterial saturation of 4.0 per cent during exercise were similar to the changes observed in the entire group of 18 patients.

\section{Discussion}

Wade and Bishop (1962) analysed their own and published data in patients with pulmonary emphysema and reported that the resting cardiac output, as judged by the "cardiac index", was abnormally high in 8 per cent of the subjects, and abnormally low in 5 per cent. However, Reeves et al. (1961b) found that the "cardiac index" varied with the age, sex, body size, and metabolic rate of the subject, and showed that the a-v oxygen difference was a better standard for assessing the "normality" of the resting cardiac output. None of the 41 emphysematous patients in the present study had an abnormally narrow a-v difference at rest, so that according to the criteria of Reeves et al. (1961b) no patient had an abnormally high cardiac output. In 6 of the 41 patients the a-v difference was wider than normal, implying an abnormally low cardiac output.

Aber et al. (1963) reported that the cardiac output was inversely proportional to the mean pulmonary artery pressure in 14 patients with "obstructive airways disease", and it might be suggested that in some emphysematous patients cardiac output is limited by pulmonary hypertension. However, no correlation could be shown between the mean pulmonary artery pressure and the a-v difference at rest in the 41 patients of the present study, and Wade and Bishop (1962) found no correlation between cardiac output and pulmonary artery pressure in their own and collected data. It seems unlikely that the cardiac output was depressed by a high pulmonary arterial pressure in the patients of the present study, since only one of the six with a-v differences above normal had marked hypertension (the mean pressures being 18, 25, 29, 26, 20, and $44 \mathrm{~mm} . \mathrm{Hg}$ ).

The ability of the heart to adapt to a high pulmonary arterial pressure in emphysema is illustrated by the normal or almost normal increase in cardiac output in response to exercise, in both the supine and erect position, which has been observed in the present study and by other recent workers (Kitchin Lowther, and Matthews, 1961 ; Cotes, Pisa, and Thomas, 1963). In fact it would be surprising if an increase in pulmonary arterial pressure of the degree seen in emphysema had much effect upon the cardiac output, since similar pressures are seen in patients with other pathological conditions and in healthy residents at high altitude, in whom the cardiac output and its response to exercise are reported to be normal. Thus, the cardiac output is usually normal in patients with kyphoscoliosis at rest and during exercise despite mean pulmonary arterial pressures as high as $50 \mathrm{~mm}$. $\mathrm{Hg}$ (Bergofsky, Turino, and Fishman, 1959). Similarly, in healthy residents at high altitude a normal cardiac output is maintained against a mean pulmonary arterial pressure as high as $62 \mathrm{~mm}$. $\mathrm{Hg}$ (Peñaloza et al., 1963). However, though the absolute pressure in the pulmonary artery does not appear to limit cardiac output, it is possible that pathological changes in the pulmonary arterial system in emphysema may have indirect effects upon the circulation. Thus, reduction of the compliance of the walls 


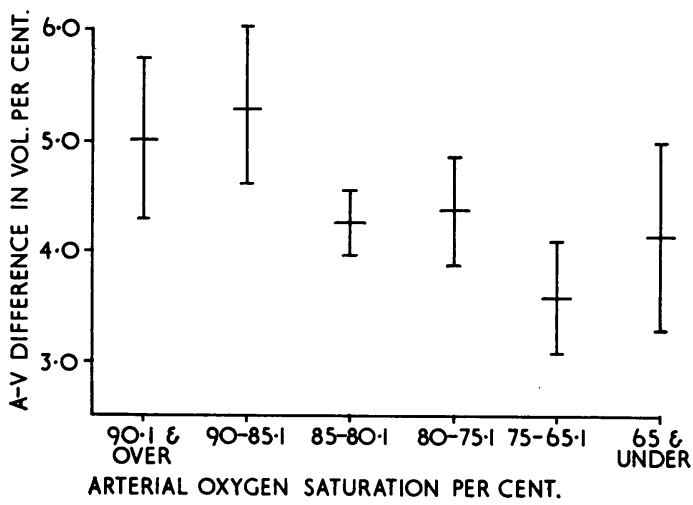

FIG. 5.-The emphysematous patients have been grouped according to their arterial oxygen saturation (at rest). The mean and twice the standard error range of the mean for the a-v oxygen difference is plotted for each group.

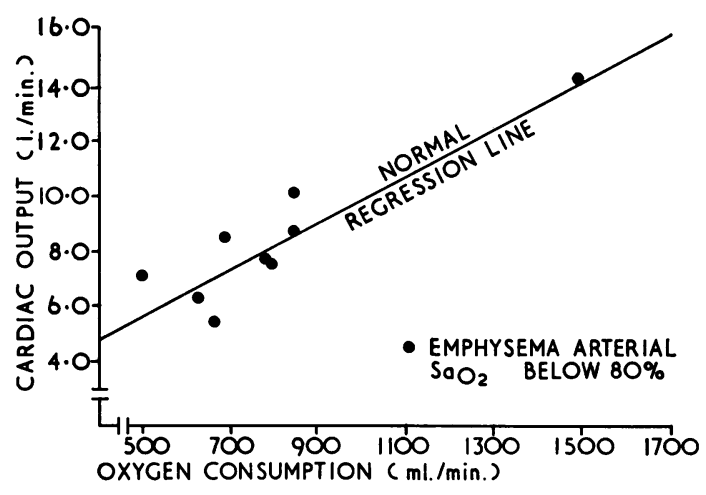

FIG. 6.-Cardiac output is plotted against oxygen consumption during treadmill exercise in 9 patients whose arterial oxygen saturations were less than 80 per cent. All the points cluster near the normal regression lines.

of the pulmonary artery will modify the pulmonary artery pressure wave form (Shaw, 1963) and may alter the pattern of ejection and work done by the right ventricle.

In the emphysematous patients in the present study the correlation between the a-v oxygen difference and the arterial oxygen saturation at rest (Fig. 5) implies that the cardiac output rises with increasing hypoxia. This is contrary to the findings of Borden et al. (1950), but in agreement with those of Cournand (1950). However, in distinction to Cournand's conclusions, the severely hypoxic patients of the present study had a normal cardiac output, and the mildly hypoxic patients tended to have a reduced output. Further, no abnormal increase in cardiac output during exercise was observed even in the more hypoxic patients (Fig. 6).

It is tempting to suggest that the basic pathology of the lungs and pulmonary vessels in the mildly hypoxic patients with a low cardiac output differs from that of the severely hypoxic patients who have a normal cardiac output. Thurlbeck and Angus (1963) in a necropsy study found that while emphysema and bronchitis frequently occur together they may also occur independently. Fletcher et al. (1963) attempted to distinguish in life between patients with severe airways obstruction with emphysema and those with airways obstruction without emphysema (who were termed "bronchitis" patients). An analysis of the patients in this study using the criteria of Fletcher et al. (1963) is presented in Table V. Compared with the patients with arterial oxygen saturations above 85 per cent, the more hypoxic patients have a higher incidence of heart failure, a slightly higher carbon dioxide content in the pulmonary arterial blood, and more disturbance of the ventilation-perfusion ratio (as measured by the steady-state carbon monoxide diffusing capacity). The less hypoxic patients had a greater abnormality of the total lung capacity and the carbon monoxide uptake. This pattern of results implies that the less hypoxic patients with an abnormally low cardiac output have more features in common with the "emphysema" patients as described by Fletcher et al. (1963) and that the more hypoxic patients with a normal cardiac output have more in common with the "bronchitis" patients of these workers. However, the difference between the groups of patients is small and does not reach the level of significance in any respect (greatest difference is in the carbon dioxide diffusing capacity where $p=0 \cdot 2-0 \cdot 1$ ). Similarly, the study of necropsy material in the 10 patients where it is available does not show any difference in the severity of the emphysema and bronchitis (assessed by the criteria of Mitchell et al., 1964) between those with a wide a-v difference and those with normal values.

Fishman, Fritts, and Cournand (1960) have shown that acute hypoxia is associated with a rise in cardiac output. However, except during an attack of acute bronchitis, the emphysematous patient 
TABLE V

Pulmonary Function Data for Groups of Emphysema Patients*

\begin{tabular}{|c|c|c|c|c|c|c|}
\hline Subjects & $\begin{array}{c}\text { History of } \\
\text { cardiac } \\
\text { failure } \\
\text { (no. of } \\
\text { patients) }\end{array}$ & $\begin{array}{c}\text { Mean } \\
\text { arterial } \\
\text { saturation } \\
(\%)\end{array}$ & $\begin{array}{c}\text { Mean PA† } \\
\text { CO }_{2} \text { content } \\
\text { (vol. } \%)\end{array}$ & $\begin{array}{l}\text { Carbon } \\
\text { monoxide } \\
\text { uptake } \\
\text { (ml./min.) }\end{array}$ & $\begin{array}{l}\text { Diffusion } \\
\text { capacity } \\
\text { for carbon } \\
\text { monoxide }\end{array}$ & $\begin{array}{c}\text { TLC } \ddagger \\
\% \\
\text { normal }\end{array}$ \\
\hline Low cardiac output & 0 & 91 & $50 \cdot 8$ & $2 \cdot 1$ & $7 \cdot 3$ & 130 \\
\hline Emphysema I & 0 & 91 & $50 \cdot 5$ & $2 \cdot 3$ & $7 \cdot 6$ & 129 \\
\hline Emphysema II & 3 & 76 & $52 \cdot 3$ & 2.5 & $5 \cdot 4$ & 124 \\
\hline
\end{tabular}

* The patients have been divided into three groups, the six with an abnormally wide a-v difference, the 16 with a resting arterial oxygen saturation above $85 \%$ (Emphysema I), and the 25 with a saturation of $85 \%$ or less (Emphysema II), and analysed by the criteria of Fletcher et al. (1963).

$\dagger$ PA, pulmonary arterial blood.

¥ TLC, total lung capacity.

\section{TABLE VI}

Comparison a-v Oxygen Difference in Vol. Per Cent Between Normal Subjects at Denver, Emphysema Patients, and Healthy Residents at High Altitude

\begin{tabular}{|c|c|c|c|c|c|c|c|}
\hline \multicolumn{4}{|l|}{ Subjects } & \multirow{2}{*}{$\begin{array}{l}\text { No. } \\
53 \\
20\end{array}$} & \multirow{2}{*}{$\begin{array}{c}\frac{\mathrm{SaO}_{2}}{\%} \\
94 \\
92\end{array}$} & \multirow{2}{*}{$\frac{\begin{array}{c}\mathrm{a}-\mathrm{v} \\
\text { difference }\end{array}}{\left.\begin{array}{l}3.98 \\
4.36\end{array}\right\}}$} & \multirow{2}{*}{$\begin{array}{c}\begin{array}{c}\text { Significance } \\
\mathrm{p}\end{array} \\
0.02-0.01\end{array}$} \\
\hline $\begin{array}{l}\text { Normals at Denver } \\
\text { Altitude residents at Leadville } \ddot{\dagger}\end{array}$ & $\begin{array}{l}\cdots \\
\cdots\end{array}$ & $\begin{array}{l}\cdots \\
\cdots\end{array}$ & $\begin{array}{l}\cdots \\
\cdots\end{array}$ & & & & \\
\hline $\begin{array}{l}\text { Emphysema I . } \\
\text { Altitude residents at Leadville } \dagger\end{array}$ & $\begin{array}{l}\cdots \\
\cdots\end{array}$ & $\begin{array}{l}\cdots \\
\cdots\end{array}$ & $\begin{array}{l}\cdots \\
\cdots\end{array}$ & $\begin{array}{l}16 \\
20\end{array}$ & $\begin{array}{l}91 \\
92\end{array}$ & $\left.\begin{array}{l}5 \cdot 03 \\
4 \cdot 36\end{array}\right\}$ & $0.02-0.01$ \\
\hline $\begin{array}{l}\text { Emphysema II .. . . } \\
\text { Altitude residents at Morococha } \ddagger\end{array}$ & $\begin{array}{l}\ldots \\
\cdots\end{array}$ & $\begin{array}{l}\ldots \\
\cdots\end{array}$ & $\begin{array}{l}\cdots \\
\cdots\end{array}$ & $\begin{array}{l}25 \\
36\end{array}$ & $\begin{array}{l}76 \\
78\end{array}$ & $\left.\begin{array}{l}4 \cdot 14 \\
4 \cdot 14\end{array}\right\}$ & $>0.9$ \\
\hline
\end{tabular}

$* \mathrm{SaO}_{2} \%=$ arterial oxygen saturation per cent.

$\dagger$ Vogel et al. (1962).

¥ Peñaloza et al. (1963).

Note: Emphysema I are those patients who had a resting arterial oxygen saturation of over 85 per cent, and Emphysema II are those whose saturation was $85 \%$ or less.

is more analogous to the chronically hypoxic mountain dweller than to the volunteer at sea-level who is rendered acutely hypoxic artificially. Healthy residents at an altitude of $14,900 \mathrm{ft}$., who were investigated by Peñaloza et al. (1963), have a similar mean arterial oxygen saturation to that of the more hypoxic emphysematous patients in the present study (those with an arterial oxygen saturation of $85 \%$ or less). The mean a-v differences of the two types of subject are identical at the value of 4.14 vol. per cent, which implies that the resting cardiac output of these severely hypoxic emphysematous patients is normal (Table VI). Residents at an altitude of 10,150 ft. studied by Vogel et al. (1962) have a similar mean arterial oxygen saturation to that of the less hypoxic emphysematous patients of the present study (those with an arterial oxygen saturation of more than $85 \%$ ). The mean a-v difference of the altitude residents is not as wide as that of the emphysematous patients, but is significantly wider than the mean for normal subjects at Denver $(\mathrm{p}<0.02$, Table VI), implying that the resting cardiac output of both types of subject is lower than the normal for Denver. Further, 3 out of the 20 altitude residents have resting a-v differences wider than the upper limit of normal for Denver (none had narrower a-v differences). Reeves et al. (1961c) have shown that the normal initial response to very mild exercise is a widening of the a-v oxygen difference, and that this occurs before an increase in cardiac output. The increased work of breathing in the emphysematous 
patient (and perhaps in the altitude resident) may constitute a form of mild exercise, and, if so, a wide a-v difference should be expected. For a given ventilatory impairment this phenomenon should be more pronounced in patients who maintain relatively normal blood gas tensions by hyperventilation, than in those with less ventilatory drive who develop significant hypoxia and carbon dioxide retention.

\section{SUMMARY}

The oxygen consumption, a-v oxygen difference, cardiac output, pulmonary artery pressure, and arterial oxygen saturation have been studied at rest in 41 patients with chronic irreversible obstructive airway disease, and during exercise in the supine position in 17 patients, and in the erect position in 18 patients. The findings have been compared with those of normal subjects studied under similar conditions in this laboratory.

At rest the mean a-v oxygen difference was significantly wider in the emphysematous patients than in the normal subjects, the values being 4.49 and 3.98 vol. per cent, respectively $(\mathrm{p}<0 \cdot 01)$. During supine exercise the cardiac output increased by a normal amount in the majority of the emphysematous patients; a slightly subnormal increase was observed in four patients. During exercise in the erect position the cardiac output increased to the same extent in the emphysematous patients as in the normal subjects.

No relationship could be shown between the a-v oxygen difference and the pulmonary artery pressure, and pulmonary hypertension did not appear to be responsible for the low cardiac output seen in some emphysematous patients.

The cardiac output tended to be normal in the severely hypoxic patients (arterial oxygen saturation $85 \%$ or less), but was abnormally low in the less hypoxic patients. These findings are compared with the results reported in normal residents at high altitude, and the similarity between the data from the two types of subject is discussed.

We are indebted to Dr. Giles F. Filley and Dr. R. S. Mitchell for pulmonary function data given in Table VI, and for details of necropsy findings. Dr. H. F. Freundlich kindly checked some of the statistical calculations.

\section{REFERENCES}

Aber, G. M., Bayley, T. J., and Bishop, J. M. (1963). Inter-relationships between renal and cardiac function and respiratory gas exchange in obstructive airways disease. Clin. Sci., 25, 159.

Anderson, L. L., Willcox, M. L., Silliman, J., and Blount, S. G., Jr. (1953). The pulmonary physiology of normal individuals living at an altitude of one mile. J. clin. Invest., 32, 490.

Barcroft, J. (1925-28). The Respiratory Function of the Blood, 2nd ed. University Press, Cambridge.

Bergofsky, E. H., Turino, G. M., and Fishman, A. P. (1959). Cardiorespiratory failure in kyphoscoliosis. Medicine (Baltimore), 38, 263.

Blount, S. G., Jr. (1959). Cardiac output in pulmonary emphysema. In Pulmonary Circulation, ed. W. R. Adams and I. Veith, p. 160. Grune and Stratton, New York. Borden, C. W., Wilson, R. H., Ebert, R. V., and Wells, H. S. (1950). Pulmonary hypertension in chronic pulmonary
emphysema. Amer. J. Med., 8, 701.

Cotes, J. E., Pisa, Z., and Thomas, A. J. (1963). Effect of breathing oxygen upon cardiac output, heart rate, ventilation, systemic and pulmonary blood pressure in patients with chronic lung diseases. Clin. Sci., 25, 305.

Cournand, A. (1950). Some aspects of the pulmonary circulation in normal man and in chronic cardiopulmonary diseases. Circulation, 2, 641.

Fishman, A. P., Fritts, H. W., and Cournand, A. (1960). Effects of acute hypoxia and exercise on the pulmonary circulation, 22, 204.

Fletcher, C. M., Hugh-Jones, P., McNicol, M. W., and Pride, N. B. (1963). The diagnosis of pulmonary emphysema in the presence of chronic bronchitis. Quart. J. Med., $32,33$.

Harvey, J. M., Ferrer, M. I., Richards, D. W., and Cournand, A. (1951). Influence of chronic pulmonary disease on the heart and circulation. Amer. J. Med., 10, 719.

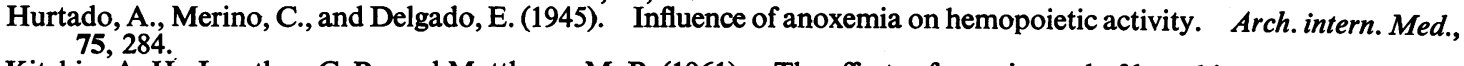

Kitchin, A. H., Lowther, C. P., and Matthews, M. B. (1961). The effects of exercise and of breathing oxygen-enriched air on the pulmonary circulation in emphysema. Clin. Sci., $21,93$. McMichael, J., and Sharpey-Schafer, E. P. (1944). The action of intravenous digoxin in man. Quart. J. Med., 13,
123.

Mitchell, R. S., Petty, T. L., Vincent, T. N., and Filley, G. F. (1964). Awaiting publication. 
Peñaloza, D., Sime, F., Banchero, N., Gamboa, R., Cruz, J., and Marticorena, E. (1963). Pulmonary hypertension in healthy men born and living at high altitudes. Amer.J. Cardiol., 11, 150.

Reeves, J. T., Glover, R. F., Blount, S. G., Jr., and Filley, G. F. (1961a). Cardiac output response to standing and treadmill walking. J. appl. Physiol., 16, 283.

- $\frac{1}{16}$, Filley, G. F., and Blount, S. G., Jr. (1961b). Cardiac output in normal resting man. J. appl. Physiol., 16, 276.

$\longrightarrow, \frac{16}{16}, 279$.

Shaw, D. B. (1963). Compliance and inertance in the pulmonary arterial system. Clin. Sci., 25, 181.

, and Simpson, T. (1961). Polycythæmia in emphysema. Quart. J. Med., 30, 135.

Thurlbeck, W. M., and Angus, G. E. (1963). The relationship between emphysema and chronic bronchitis as assessed morphologically. Amer. Rev. resp. Dis., 87, 815.

Vogel, J. H. K., Weaver, W. F., Rose, R. L., Blount, S. G., Jr., and Gover, R. F. (1962). Pulmonary hypertension on exertion in normal man living at 10,150 feet (Leadville, Colorado). Med. thorac. (Basel), $19,461$.

Wade, O. L., and Bishop, J. M. (1962). Cardiac Output and Regional Blood Flow. Blackwell, Oxford.

Williams, M. H., and Zohman, L. R. (1959). Cardiopulmonary function in chronic obstructive emphysema. Amer. Rev. resp. Dis., 80, 689.

Wilson, R. H., Borden, C. W., and Ebert, R. V. (1951). Adaptation to anoxia in chronic pulmonary emphysema. Arch. intern. Med., 88, 581 .

Yu, P. N. G., Lovejoy, F. W., Joos, H. A., Nye, R. E., and McCann, W. S. (1953). Studies of pulmonary hypertension I. Pulmonary circulatory dynamics in patients with pulmonary emphysema at rest. J. clin. Invest., $32,130$. 